University of Nebraska - Lincoln

DigitalCommons@University of Nebraska - Lincoln

Agronomy \& Horticulture -- Faculty Publications

Agronomy and Horticulture Department

$5-1980$

\title{
Inheritance of Flower Color in Musk Thistle (Carduus thoermeri)
}

M. K. McCarty

Francis A. Haskins

University of Nebraska-Lincoln, fhaskins@neb.rr.com

H. J. Gorz

University of Nebraska-Lincoln

Follow this and additional works at: https://digitalcommons.unl.edu/agronomyfacpub

Part of the Plant Sciences Commons

McCarty, M. K.; Haskins, Francis A.; and Gorz, H. J., "Inheritance of Flower Color in Musk Thistle (Carduus thoermeri)" (1980). Agronomy \& Horticulture -- Faculty Publications. 154.

https://digitalcommons.unl.edu/agronomyfacpub/154

This Article is brought to you for free and open access by the Agronomy and Horticulture Department at DigitalCommons@University of Nebraska - Lincoln. It has been accepted for inclusion in Agronomy \& Horticulture -Faculty Publications by an authorized administrator of DigitalCommons@University of Nebraska - Lincoln. 


\title{
Inheritance of Flower Color in Musk Thistle (Carduus thoermeri) ${ }^{1}$
}

\author{
M. K. MCCARTY, H. J. GORZ, and F. A. HASKINS ${ }^{2}$
}

\begin{abstract}
Four flower-color phenotypes were observed in a population of musk thistle (Carduus thoermeri Weinm.). This plant has been commonly referred to as $C$. nutans $L$. The four phenotypes were: purple corolla and purple pollen, pink corolla and white pollen, white corolla and purple pollen, and white corolla and white pollen. In four generations, 177 self-pollinated individuals of these four phenotypes produced 2123 progeny plants that were classified. Results support the hypothesis that three independent gene pairs were involved in determining the four flower phenotypes. The gene pairs have been designated $P / p, W / w$, and $P i / p i$. It was postulated that all three dominant alleles, $P, W$, and $P i$, must be present to produce both purple corollas and purple pollen. The $p$ allele prevents color development in both corollas and pollen; the $w$ allele eliminates color in corollas but does not affect pollen color; and the pi allele dilutes corolla color from purple to pink and eliminates pollen color. Height measurements of progenies of self-pollinated plants indicated that decreased plant height was associated with inbreeding. On the basis of the evidence presented, the musk thistle plants used in these experiments appear to belong to a single species.

Additional index words: Inbreeding, Carduus nutans, Carduus macrocephalus.
\end{abstract}

\section{INTRODUCTION}

Musk thistle is the common name used for the largeflowered plants in the genus Carduus found across much of the United States and southern Canada. Three species are probably involved, Carduus nutans L., C. macrocephalus Desf., and C. thoermeri Weinm., with the major populations being Carduus thoermeri Weinm. Associated with these plants at many locations is the small-flowered plumeless thistle (Carduus acantboides L.).

None of the species in the genus Carduus is native to North America. All were introduced from Europe. Time and means of introduction are not known, but the earliest recorded occurrence was in central Pennsylvania in 1852 (6). There are numerous records of occurrence in the later 1800 s along the East Coast, often associated with ballast in the dock areas. ${ }^{3}$ Records of Carduus plants in the Midwest began to appear near the turn of the century.

From this sparse beginning, musk thistle apparently found environments to which it was particularly well adapted. By the early 1940 s musk thistle began to be mentioned as a potential

\footnotetext{
${ }^{1}$ Received for publication October 5, 1979. Contribution from Agric. Res., Sci. Ed. Admin., U.S. Dep. Agric., and the Nebraska Agric. Exp. Stn., Published as Paper No. 5787, J. Series, Nebraska Agric. Exp. Stn.

${ }^{2}$ Superv. Res. Agron. and Superv. Res. Geneticist, Agric. Res., Sci. Ed. Admin., U.S. Dep. Agric. and George Holmes Prof. Agron., Univ. of Nebraska, Lincoln, NE 68583.

${ }^{3}$ Study by the senior author of Carduus holdings of the following herbaria: Duke Univ.; Field Museum of Natural History,, Chicago; Gray Herbarium; Iowa State Univ.; L. H. Bailey Hortorium, Cornell Univ.; Missouri Botanical Garden; New York Botanical Garden; Pennsylvania State Univ.; Univ. of British Columbia; Univ. of California, Berkeley; Univ. of California, Davis; Univ. of Kentucky; Univ. of Michigan; Univ. of Nebraska; Univ. of Wisconsin; Virginia Polytechnic Institute.
}

weed problem. In 1959 musk thistle was added to the Nebraska State Department of Agriculture list of noxious weeds, and plumeless thistle was added to this list in 1965.

Since 1960 a nursery of thistle plants including musk and plumeless thistles, several species of Cirsium, and Scotch thistle (Onopordum acantbium L.) has been maintained on the Lincoln campus of the University of Nebraska. Initially all of the musk thistle entries were purple-flowered. Several years after the collection was started, however, plants from a population of white-flowered musk thistle, discovered near Cheney, Nebraska, in 1965 , were added to the nursery.

Moore and Frankton (3) described $C$. nutans and $C$. acantboides and a hybrid of the two (as $C$. $\chi$ ortbecepbalus). They listed a white-flower variant as $C$. $\chi$ ortbocephalus $\mathrm{f}$. mulliganii Boivin. Moore and Mulligan $(4,5)$ described in some detail a population of the hybrid found in Gray County, Ontario.

Fuller (1), in studying Carduus in Nebraska, indicated that almost all of the plants she found appeared to be the products of interbreeding between $C$. nutans and $C$. acantboides. She alluded to this as an instance of plants extending their range through hybridization.

In 1973 , observation in the nursery, where both purple and white-flowered musk thistle and plumeless thistle had been growing in adjacent areas for several years, revealed an additional color variant, white corollas with purple pollen. The occurrence of this variant form suggested the possibility that natural crossing might have taken place between the purpleflowered (all of which had purple pollen) and white-flowered (which typically had white pollen) forms. Plants of these three color phenotypes were studied with the primary objective of elucidating the genetics of flower color in musk thistle. As a part of the study, information also was obtained on the influence of inbreeding on plant height.

\section{MATERIALS AND METHODS}

Musk thistle plants were propagated under nursery conditions by starting seedlings in late July, growing the seedlings in peat pots until mid - to late-August, and then transplanting them to the nursery. This procedure allowed tillage and soil preparation until time of transplanting, with reduction in need for weed control. The success of this procedure depended on the fact that musk thistle, which is primarily a biennial plant (2), behaves as a winter annual under conditions of limited competition. Seedlings were placed in rows about $230 \mathrm{~cm}$ apart and spaced at $150-\mathrm{cm}$ intervals in the row to allow complete access to plants when they approached maturity.

In 1973 , quantities of seed were collected from plants that had (a) purple corollas and pollen, (b) white corollas and pollen, or (c) white corollas and purple pollen. Five lots of seed were collected; each lot included bulked seed from several plants of one of the color phenotypes. Two of the lots were harvested from plants of type (a), two from type (b), and one 


\section{WEED SCIENCE}

from type (c). Two replications (one nursery row of each seed lot per replication) were established during the summer and fall of 1973. In 1974, selected heads were bagged with finemesh, muslin selfing bags just before the start of anthesis. Bagging was delayed until this stage to permit heads to develop as much as possible before the bags were applied. The bagged heads were left on the plants for a period of 10 days to 2 weeks after anthesis to ensure full maturity of the seed before they were harvested, dried, and processed.

To supplement the progenies grown in the nursery, additional lines were grown in the greenhouse each season. These seedlings were started at the same time as the nursery seedlings and were transplanted into $20-\mathrm{cm}$ pots in the greenhouse. By mid-September the potted rosettes, which had grown to a diameter of 7 to $14 \mathrm{~cm}$, were placed outside to become vernalized. They were left outside for several weeks of lowering temperatures and were returned to the greenhouse only when temperatures below $-15 \mathrm{C}$ were expected.

The 1974 nursery contained an additional color type segregate, plants with pink corollas and white pollen. Subsequent selections for selfing included plants of all four color phenotypes. During the years of 1975,1976 , and 1977, plants were chosen for selfing by color as well as by the sequence of colors in the preceding years.

From 1974 to 1978 , height was measured in samples of plants in each nursery. In 1974,10 plants per row of openpollinated progenies of plants with purple corollas and pollen, white corollas and pollen, and white corollas and purple pollen were used for the height measurements. In subsequent years, either five or six plants were measured in each row of selfed progeny. The height of the terminal flower was recorded at full bloom. Flower colors of all measured plants also were recorded.

\section{RESULTS AND DISCUSSION}

Flower color inberitance. The symbols $\mathrm{P}, \mathrm{Pi}, \mathrm{Wp}$, and $\mathrm{W}$ are used to designate the flower color types that have, respectively, purple corrollas and pollen, pink corollas and white pollen, white corollas and purple pollen, and white corollas and pollen. Progenies of a total of 177 selfed plants were classified for flower color during the $4 \mathrm{yr}$ of the study (Table 1). Relatively early in the study, it was observed that W plants, when selfed, produced only $W$ offspring. Selfed Wp plants produced either all Wp progeny or a mixture of $\mathrm{Wp}$ and W plants. Similary, selfed Pi plants yielded either all $\mathrm{Pi}$ offspring or a mixture of $\mathrm{Pi}$ and $\mathrm{W}$ plants. Selfed $\mathrm{P}$ plants produced all $\mathrm{P}$ offspring or mixtures of $\mathrm{P}$ and one, two, or all three of the other color phenotypes. No types other than $P$, $\mathrm{Pi}, \mathrm{Wp}$, and $\mathrm{W}$ were observed.

Inasmuch as four and only four flower phenotypes were observed, it was reasonable to postulate that flower color might be controlled primarily by two allelic pairs. The doubly dominant genotype might be expected to produce the $\mathrm{P}$ phenotype, the double recessive might be $\mathrm{W}$, and the $\mathrm{Pi}$ and Wp phenotypes might result from the presence of single dominants. The expected phenotypic ratio in the progeny of a selfed, doubly heterozygous plant, assuming no linkage between the two genes, would be $9 \mathrm{P}: 3 \mathrm{Pi}: 3 \mathrm{Wp}: 1 \mathrm{~W}$. Al- though the simplicity of this two-gene hypothesis was attractive, the hypothesis proved untenable, primarily for the following reasons: (a) among the progenies of $P$ plants in which all four flower phenotypes were present, some progenies appeared to fit a 9:3:3:1 quite well, but other progenies had far too many $W$ plants to fit this ratio; and (b) progenies of some $\mathrm{P}$ plants included three phenotypes, and some of these progenies appeared to fit a $9 \mathrm{P}: 3 \mathrm{Pi}: 4 \mathrm{~W}$ ratio reasonably well, whereas others appeared to fit a $9 \mathrm{P}: 3 \mathrm{Wp}: 4 \mathrm{~W}$ ratio. No simple two-gene hypothesis could account for these observations; therefore, a three-gene model was hypothesized.

The three independent gene pairs and their effects are postulated as:

$P / p: \quad$ The $P$ allele is necessary for the development of color in both corolla and pollen; $p$ gives white corolla and pollen.

$W / w$ : The $W$ allele is required for corolla color but not for pollen color; $w$ plants may have white corollas but purple pollen.

$P i / p i$ : In combination with $P$ and $W, P i$ is required for the production of purple corollas and purple pollen; $p i$ combines with $P$ and $W$ for pink corollas and white pollen.

Stated in a slightly different manner, the hypothesis suggests that the three dominant alleles, $P, W$, and $P i$, must be present to produce both purple corollas and purple pollen. The $p$ allele prevents color development in both corollas and pollen; the $w$ allele prevents color formation in corollas but does not affect pollen color; and the pi allele dilutes corolla color from purple to pink and eliminates pollen color.

Given these three allelic pairs and the effects indicated, the phenotypes expected from selfing a triple heterozygote are as shown in Table 2. It is noteworthy that although three gene pairs are shown, there are only four phenotypes, and the expected phenotypic ratio, assuming independence of the three genes, is $27 \mathrm{P}: 9 \mathrm{Pi}: 9 \mathrm{Wp}: 19 \mathrm{~W}$. Heterozygosity at two of the three loci in a selfed plant is expected to result in a 9:3:3:1 phenotypic ratio or some modification thereof, and various $3: 1$ ratios can result from heterozygosity at each locus individually.

Progenies from each of the 177 selfed plants were assigned to the conventional ratio that seemed to fit most closely, and the results from these pooled data were compared with the respective standard ratios by use of the chi-square test. As shown in Table 3 , none of the observed ratios deviated significantly from the expected ratios. These chi-square calculations also included determinations of chi-squares for heterogeneity among the families descended from the five seed lots used in establishing the musk thistle nursery in the fall of 1973. None of the heterogeneity chi-square values was significant $(P=0.05)$; thus, pooling data from all five familes was justified.

Table 3 includes a listing of the genotypes proposed for most of the 177 selfed plants included in this study. The close fits between observed and expected ratios shown in this table supported most of these genotypic designations very well. Verification of all genotypes by progeny testing was not possible, thus; 30 of the 55 plants selfed in 1975 came from 
Table 1. Summary, by years and phenotypes, of numbers of selfed musk thistle plants and numbers of progeny plants grown from them at Lincoln, Nebraska.

\begin{tabular}{|c|c|c|c|c|c|}
\hline \multirow[t]{2}{*}{$\begin{array}{l}\text { Year } \\
\text { of } \\
\text { selfing }\end{array}$} & \multirow{2}{*}{$\begin{array}{l}\begin{array}{l}\text { Phenotype } \\
\text { of selfed } \\
\text { plant }^{2}\end{array} \\
\mathrm{P} \\
\mathrm{Pi} \\
\mathrm{Wp} \\
\mathrm{W}\end{array}$} & \multicolumn{2}{|c|}{$\begin{array}{l}\text { Number } \\
\text { of selfed } \\
\text { plants }\end{array}$} & \multicolumn{2}{|c|}{$\begin{array}{l}\text { Number of progeny } \\
\text { plants grown from } \\
\text { selfed plants }\end{array}$} \\
\hline & & $\begin{array}{r}19 \\
2 \\
13 \\
10\end{array}$ & 44 & $\begin{array}{r}372 \\
41 \\
246 \\
163\end{array}$ & 822 \\
\hline 1975 & $\begin{array}{l}P \\
\mathrm{Pi} \\
\mathrm{Wp} \\
\mathrm{W}\end{array}$ & $\begin{array}{r}22 \\
7 \\
15 \\
11\end{array}$ & 55 & $\begin{array}{r}290 \\
90 \\
166 \\
145\end{array}$ & 691 \\
\hline 1976 & $\begin{array}{l}P \\
\mathrm{Pi} \\
\mathrm{Wp} \\
\mathrm{W}\end{array}$ & $\begin{array}{r}20 \\
7 \\
18 \\
5\end{array}$ & 50 & $\begin{array}{r}155 \\
55 \\
121 \\
26\end{array}$ & 357 \\
\hline 1977 & $\begin{array}{l}\mathrm{P} \\
\mathrm{Pi} \\
\mathrm{Wp}_{\mathrm{p}} \\
\mathrm{W}\end{array}$ & $\begin{array}{r}14 \\
3 \\
8 \\
3\end{array}$ & 28 & $\begin{array}{r}104 \\
21 \\
91 \\
37\end{array}$ & 253 \\
\hline $\begin{array}{l}4 \text {-year } \\
\text { totals }\end{array}$ & $\begin{array}{l}\mathrm{P} \\
\mathrm{Pi} \\
\mathrm{Wp} \\
\mathrm{W}\end{array}$ & $\begin{array}{l}75 \\
19 \\
54 \\
29\end{array}$ & 177 & $\begin{array}{l}921 \\
207 \\
624 \\
371\end{array}$ & 2123 \\
\hline
\end{tabular}

${ }^{\mathrm{a}}$ Phenotype abbreviations: $\mathrm{P}$ - purple corollas and pollen; $\mathrm{Pi}$ - pink corollas and white pollen; $\mathrm{W} p$ - white corollas and purple pollen; W white corollas and pollen.

six P plants selfed in 1974 , and 44 of the 50 plants selfed in 1976 and 27 of the 28 plants selfed in 1977 were descended from these same six P plants. These $101(30+44+27)$ selfed plants, plus the six selfed plants from which they came, accounted for 1073 of the progeny plants examined in this study. Consideration of the progenitors and progenies of these 107 selfed plants permitted reasonably definite assignment of genotypes to 100 of them. The segregations observed in the progenies of these 100 plants were compared with the ratios expected on the basis of the assigned genotypes. Results (Table 4) indicated no significant deviation from the expected ratios except in the case of the selfed $P P W w P i P i$ plants, which were expected to produce offspring with a ratio of $3 \mathrm{P}: 1 \mathrm{Wp}$. The observed ratio was closer to $2 \mathrm{P}: 1 \mathrm{Wp}$ for reasons that were not clear. Sampling vagaries provide a possible explanation.

The customary way to test genetic hypotheses is to make specific crosses and observe the resulting progenies. For example, if the gene effects and genotypes we have postulated are correct, it should be possible to cross two $\mathrm{W}$ plants, one having the PPwwpipi genotype and the other the $p p W W P i P i$ genotype, to produce $\mathrm{F}_{1}$ plants of the $\mathrm{P}$ phenotype. A Pi plant, genotype $P P W W p i p i$, crossed with a Wp plant, genotype $P P w w P i P i$, also should produce $\mathrm{F}_{1}$ plants of the $\mathrm{P}$ phenotype. Numerous other interesting crosses could be made if controlled crossing were possible. Unfortunately, all at-
Table 2. Flower phenotypes and expected frequencies in the progeny of a self-pollinated PpWwPipi musk thistle plant.

\begin{tabular}{|c|c|c|c|c|}
\hline \multirow{2}{*}{$\begin{array}{l}\text { Abbrevi- } \\
\text { ated } \\
\text { symbol } \\
\text { for } \\
\text { phenotype }\end{array}$} & \multicolumn{2}{|c|}{ Color of } & \multirow{2}{*}{$\begin{array}{l}\text { Pheno- } \\
\text { type } \\
\text { desig- } \\
\text { nation }\end{array}$} & \multirow{2}{*}{$\begin{array}{l}\text { Ex- } \\
\text { pected } \\
\text { fre- } \\
\text { quency }\end{array}$} \\
\hline & Corolla & Pollen & & \\
\hline $\mathrm{P}$ & Purple & Purple & $P W P i$ & 27 \\
\hline $\mathrm{Pi}$ & Pink & White & $P W p i$ & 9 \\
\hline Wp & White & Purple & $P w P i$ & 9 \\
\hline w & White & White & Pwpi & 3 \\
\hline W & White & White & $p W P i$ & 9 \\
\hline W & White & White & $p W p i$ & 3 \\
\hline W & White & White & $p w P i$ & 3 \\
\hline W & White & White & pwpi & 1 \\
\hline
\end{tabular}

tempts at making such crosses failed. These attempts were made by bagging heads of selected plants until stigmas had expanded, then dusting pollen from other selected plants on these stigmas and rebagging the heads. No seed developed in heads treated in this manner. Therefore, no data on controlled crosses are available. However, we believe that the results based on progenies of selfed plants strongly support the postulated genes and the effects proposed for each of them.

Effect of inbreeding on plant beight. Heights of plants of each of the color phenotypes for each year during the period 1974 through 1979 are shown in Table 5. At the start of the study in 1974 , Wp plants were taller than P plants, which were taller than $W$ plants. The reasons for these height differences, which persisted through the first $3 \mathrm{yr}$ of the study, are not obvious. Plants of the $\mathrm{Pi}$ phenotype were consistently shortest of the four phenotypes after their appearance in the 1974 nursery.

Except for the 1974 height data, all measurements of plant height were based on progenies of self-pollinated plants. The data indicate a strong tendency for plant height to decrease as extent of inbreeding (i.e., generations of selfing) increased. This effect of inbreeding is typical of species in which a considerable amount of cross-pollination normally occurs, and it suggests that cross-pollination in musk thistle may be extensive.

The height decrease was not uniform over years (Table 5), probably because of variations in such environmental factors as rainfall and temperature. There is no doubt, however, that the decreases were real and that they were associated with inbreeding. Open-pollinated musk thistle progenies grown in nurseries adjacent to the flower color nursery were considerably taller than the progenies of selfed plants. Unfortunately, no height measurements were made on these open-pollinated plants.

If cross-pollination in musk thistle is extensive, then the possibility of interspecific hybridization between musk thistle and plumeless thistle must be considered. The nursery included plants of both musk thistle and plumeless thistle grown in close proximity for the $13-y r$ period before these experi- 


\section{WEED SCIENCE}

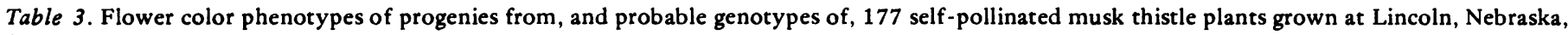
from 1975 to 1978 .

\begin{tabular}{|c|c|c|c|c|c|c|c|c|c|c|c|c|c|}
\hline \multirow{3}{*}{$\begin{array}{l}\text { Pheno- } \\
\text { type of } \\
\text { selfed } \\
\text { plants }^{a}\end{array}$} & \multirow{3}{*}{$\begin{array}{l}\text { No. of } \\
\text { selfed } \\
\text { plants }\end{array}$} & \multirow{2}{*}{\multicolumn{5}{|c|}{$\begin{array}{l}\text { Phenotype ratios, pooled } \\
\text { progenies of selfed plants }\end{array}$}} & \multicolumn{6}{|c|}{ Chi-square calculations } & \multirow{3}{*}{$\begin{array}{l}\text { Probable genotype } \\
\text { of selfed plants }\end{array}$} \\
\hline & & & & & & & & Ratic & ed & & & & \\
\hline & & $\mathbf{P}$ & $\mathbf{P i}$ & $\mathrm{Wp}$ & W & Total & $\overline{\mathbf{P}}$ & $\mathrm{Pi}$ & $\overline{W p}$ & $\bar{W}$ & $x^{2}$ & P values & \\
\hline $\mathbf{P}$ & 15 & 129 & 0 & 0 & 0 & 129 & \multicolumn{6}{|c|}{ No test } & PPWWpipi \\
\hline $\mathbf{P}$ & 5 & 26 & 0 & 0 & 11 & 37 & 3 & 0 & 0 & 1 & 0.441 & $0.70-0.50$ & $P p W W P i P i$ \\
\hline $\mathbf{P}$ & 25 & 237 & 0 & 94 & 0 & 331 & 3 & 0 & 1 & 0 & 2.040 & $0.20-0.10$ & $P P W w P i P i$ \\
\hline $\mathbf{P}$ & 18 & 145 & 0 & 49 & 58 & 252 & 9 & 0 & 3 & 4 & 0.537 & $0.80-0.70$ & $P p W w P i P i$ \\
\hline $\mathbf{P}$ & 4 & 30 & 7 & 0 & 8 & 45 & 9 & 3 & 0 & 4 & 2.052 & $0.50-0.30$ & $P p W W P i p i$ \\
\hline $\mathbf{P}$ & 5 & 39 & 9 & 16 & 6 & 70 & 9 & 3 & 3 & 1 & 2.534 & $0.50-0.30$ & $P P W w P i p i$ \\
\hline $\mathbf{P}$ & 3 & 22 & 9 & 8 & 18 & 57 & 27 & 9 & 9 & 19 & 0.364 & $0.95-0.90$ & $P p W w P i p i$ \\
\hline $\mathrm{Pi}$ & 9 & 0 & 98 & 0 & 0 & 98 & \multicolumn{6}{|c|}{ No test } & $P P W W p i p i$ \\
\hline $\mathbf{P i}$ & 5 & 0 & 48 & 0 & 14 & 62 & 0 & 3 & 0 & 1 & 0.194 & $0.70-0.50$ & $P-W-p i p i \mathrm{~b}$ \\
\hline $\mathrm{Pi}$ & 5 & 0 & 29 & 0 & 18 & 47 & 0 & 9 & 0 & 7 & 0.567 & $0.50-0.30$ & PpWwpipi \\
\hline Wp & 36 & 0 & 0 & 405 & 0 & 405 & \multicolumn{6}{|c|}{ No test } & $P P w w P i P i$ \\
\hline$w p$ & 16 & 0 & 0 & 156 & 42 & 198 & 0 & 0 & 3 & 1 & 1.515 & $0.30-0.20$ & $P-w w P i_{-} c$ \\
\hline$W p$ & 2 & 0 & 0 & 13 & 8 & 21 & 0 & 0 & 9 & 7 & 0.272 & $0.70-0.50$ & PpwwPipi \\
\hline $\mathbf{w}$ & 29 & 0 & 0 & 0 & 371 & 371 & \multicolumn{6}{|c|}{ No test } & pp-... or \\
\hline Total & 177 & & & & & 2123 & & & & & & & \\
\hline
\end{tabular}

\footnotetext{
${ }^{a}$ See Table 1 footnote for phenotype abbreviations.

${ }^{\mathrm{b}}$ PpWWpipi or PPWwpipi.

${ }^{c_{P p w w P i P i} \text { or PPwwPipi. }}$

$\mathrm{d}_{\text {Numerous possibilities. }}$
}

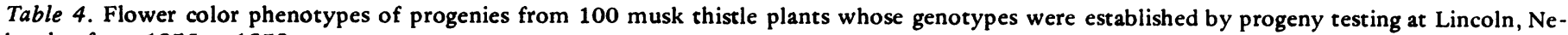
braska, from 1975 to 1978 .

\begin{tabular}{|c|c|c|c|c|c|c|c|c|c|c|c|c|c|}
\hline \multirow{3}{*}{$\begin{array}{l}\text { Pheno- } \\
\text { type } \\
\text { of selfed } \\
\text { plants }^{2}\end{array}$} & \multirow{3}{*}{$\begin{array}{l}\text { Geno- } \\
\text { type } \\
\text { of selfed } \\
\text { plants }\end{array}$} & \multirow{3}{*}{$\begin{array}{l}\text { Number } \\
\text { of } \\
\text { selfed } \\
\text { plants }\end{array}$} & \multicolumn{9}{|c|}{ Phenotypic ratios, pooled progenies of selfed plants } & \multirow[b]{3}{*}{$x^{2}$} & \multirow[b]{3}{*}{ P values } \\
\hline & & & \multicolumn{5}{|c|}{ Observed } & \multicolumn{4}{|c|}{ Expected } & & \\
\hline & & & $\overline{\mathbf{P}}$ & $\mathrm{Pi}$ & Wp & $\mathbf{W}$ & Total & $\overline{\mathbf{P}}$ & $\mathrm{Pi}$ & $\mathrm{Wp}$ & $\overline{\mathbf{W}}$ & & \\
\hline $\mathbf{P}$ & $P P W W P i P i$ & 13 & 121 & 0 & $\mathbf{0}$ & 0 & 121 & All & 0 & 0 & 0 & \multicolumn{2}{|l|}{ No test } \\
\hline $\mathbf{P}$ & $P p W W P i P i$ & 5 & 26 & 0 & 0 & 11 & 37 & 3 & 0 & 0 & 1 & 0.440 & $0.50-0.70$ \\
\hline $\mathbf{P}$ & $P P W w P i P i$ & 15 & 112 & 0 & 54 & $\mathbf{0}$ & 166 & 3 & 0 & 1 & 0 & 5.020 & $0.02-0.05$ \\
\hline $\mathbf{P}$ & $P p W w P i P i$ & 14 & 104 & 0 & 34 & 48 & 186 & 9 & 0 & 3 & 4 & 0.074 & $0.95-0.98$ \\
\hline $\mathbf{P}$ & $P p W W P i p i$ & 2 & 13 & 2 & 0 & 4 & 19 & 9 & 3 & 0 & 4 & 1.303 & $0.50-0.70$ \\
\hline $\mathbf{P}$ & $P P W w P i p i$ & 3 & 21 & 4 & 11 & 4 & 40 & 9 & 3 & 3 & 1 & 4.266 & $0.20-0.30$ \\
\hline $\mathbf{P}$ & $P p W w P i p i$ & 2 & 19 & 7 & 5 & 12 & 43 & 27 & 9 & 9 & 19 & 0.418 & $0.90-0.95$ \\
\hline $\mathrm{Pi}$ & PPWWpipi & 5 & 0 & 37 & 0 & 0 & 37 & 0 & All & 0 & 0 & \multicolumn{2}{|c|}{ No test } \\
\hline $\mathrm{Pi}$ & PpWWpipi & 3 & 0 & 15 & 0 & 7 & 22 & 0 & 3 & 0 & 1 & 0.550 & $0.30-0.50$ \\
\hline $\mathbf{P i}$ & PPWwpipi & 3 & 0 & 29 & 0 & 8 & 37 & 0 & 3 & 0 & 1 & 0.230 & $0.50-0.70$ \\
\hline Wp & $P P w w P i P i$ & 18 & 0 & 0 & 152 & 0 & 152 & 0 & 0 & All & 0 & \multicolumn{2}{|l|}{ No test } \\
\hline Wp & $P p w w P i P i$ & 9 & 0 & 0 & 63 & 22 & 85 & 0 & 0 & 3 & 1 & 0.040 & $0.80-0.90$ \\
\hline$W p$ & PPwwPipi & 3 & 0 & 0 & 22 & 8 & 30 & 0 & 0 & 3 & 1 & 0.040 & $0.80-0.90$ \\
\hline W & $p p W W P i P i$ & 2 & 0 & 0 & $\mathbf{0}$ & 16 & 16 & 0 & 0 & 0 & All & \multicolumn{2}{|c|}{ No test } \\
\hline W & $p p W W p i p i$ & 1 & 0 & 0 & 0 & 10 & 10 & 0 & $\mathbf{0}$ & 0 & All & \multicolumn{2}{|l|}{ No test } \\
\hline $\mathbf{W}$ & PPwwpipi & 2 & $\mathbf{0}$ & 0 & $\mathbf{0}$ & 19 & 19 & 0 & 0 & 0 & All & \multicolumn{2}{|l|}{ No test } \\
\hline Total & & 100 & & & & & 1020 & & & & & & \\
\hline
\end{tabular}

\footnotetext{
${ }^{a}$ See Table 1 footnote for phenotype abbreviations.
} 
Table 5. Heights of musk thistle plants of the $\mathrm{P}, \mathrm{Pi}, \mathrm{Wp}$, and $\mathrm{W}$ phenotypes grown at Lincoln, Nebraska. The 1974 plants were grown from openpollinated seed; 1975, 1976, 1977, and 1978 plants resulted from 1, 2, 3, and 4 generations of selfing, respectively.

\begin{tabular}{|c|c|c|c|c|c|}
\hline Year & Statistic & \multicolumn{4}{|c|}{ Color phenotype ${ }^{a}$} \\
\hline 1975 & $\begin{array}{l}\text { Number } \\
\bar{x}(\mathrm{~cm}) \\
s \bar{x}(\mathrm{~cm})\end{array}$ & $\begin{array}{r}64 \\
126 \\
2.9\end{array}$ & $\begin{array}{c}15 \\
97 \\
5.8\end{array}$ & $\begin{array}{r}62 \\
134 \\
2.7\end{array}$ & $\begin{array}{c}38 \\
120 \\
3.1\end{array}$ \\
\hline 1976 & $\begin{array}{l}\text { Number } \\
\bar{x}(\mathrm{~cm}) \\
\mathrm{s} \bar{x}(\mathrm{~cm})\end{array}$ & $\begin{array}{r}49 \\
128 \\
3.5\end{array}$ & $\begin{array}{r}26 \\
114 \\
6.2\end{array}$ & $\begin{array}{r}51 \\
132 \\
2.9\end{array}$ & $\begin{array}{c}46 \\
121 \\
3.6\end{array}$ \\
\hline 1977 & $\begin{array}{l}\text { Number } \\
\overline{\mathbf{x}}(\mathrm{cm}) \\
\mathrm{s} \overline{\mathbf{x}}(\mathrm{cm})\end{array}$ & $\begin{array}{l}47 \\
98 \\
2.5\end{array}$ & $\begin{array}{c}7 \\
81 \\
6.0\end{array}$ & $\begin{array}{c}43 \\
94 \\
2.6\end{array}$ & $\begin{array}{c}8 \\
95 \\
4.5\end{array}$ \\
\hline
\end{tabular}

${ }^{a}$ See Table 1 footnote for phenotypic abbreviations.

ments were started. These two species are readily distinguished from each other by traits such as head size, aggregation of heads on the branches, and shape and hairiness of leaves. If any of the plants included in our experiments had been the results of hybridization between musk thistle and plumeless thistle, the self-pollination of these hybrids should have yielded some progeny plants that resembled the plumeless thistle parent. No such progeny plants were observed. Therefore, no evidence for hybridization between these two species was found in our studies. The plants included in our experiments exhibited variation in flower color and plant height, as has been discussed. These variations may be explained by intraspecific genetic effects. With respect to other traits, the plants remained uniform throughout the $5 \mathrm{yr}$ of the study. We suggest, therefore, that the musk thistle population used in these studies represents a single plant species.

\section{LITERATURE CITED}

1. Fuller, Marian J. 1969. The genus Carduus L. in Nebraska. Univ. of Nebraska Studies No. 39. Univ. of Nebraska Press, Lincoln, Nebraska. 57 pp.

2. McCarty, M. K. and C. J. Scifres. 1969. Life cycle studies with musk thistle. Nebraska Agric. Exp. Stn. Res. Bull. 230. 15 pp.

3. Moore, R. J. and C. Frankton. 1974. The thistles of Canada. Canada Dep. Agric., Monogr. No. 10.111 pp.

4. Moore, R. J. and G. A. Mulligan. 1956. Natural hybridization between Carduus acantboides and Carduus nutans in Ontario. Can. J. Bot. 39:21-33.

5. Moore, R. J. and G. A. Mulligan. 1964. Further studies on natural selection among hybrids of Carduus acantboides and Carduus nutans. Can. J. Bot. 42:1605-13.

6. Stuckey, R. L. and J. L. Forsyth. 1971. Distribution of naturalized Carduus nutans (Compositae) mapped in relation to geology in northwestern Ohio. Ohio J. Sci. 71:1-15. 